\title{
The taxonomic consideration of floral morphology in the Persicaria sect. Cephalophilon (Polygonaceae)
}

\author{
Min-Jung KONG and Suk-Pyo HONG* \\ Laboratory of Plant Systematics, Department of Biology, Kyung Hee University, Seoul 02447, Korea
}

(Received 29 June 2018; Accepted 12 July 2018)

\begin{abstract}
A comparative floral morphological study of 19 taxa in Persicaria sect. Cephalophilon with four taxa related to Koenigia was conducted to evaluate the taxonomic implications. The flowers of $P$. sect. Cephalophilon have (four-)five-lobed tepals; five, six, or eight stamens, and one pistil with two or three styles. The size range of each floral characteristic varies according to the taxa; generally P. humilis, P. glacialis var. glacialis and Koenigia taxa have rather small floral sizes. The connate degrees of the tepal lobes and styles also vary. The tepal epidermis consists of elongated rectangular cells with variation of the anticlinal cell walls (ACWs). Two types of glandular trichomes are found. The peltate glandular trichome (PT) was observed in nearly all of the studied taxa. The PT was consistently distributed on the outer tepal of $P$. sect. Cephalophilon, while Koenigia taxa and P. glacialis var. glacialis had this type of trichome on both sides of the tepal. P. criopolitana had only long-stalked pilate-glandular trichomes (LT) on the outer tepal. The nectary is distributed on the basal part of the inner tepal, with three possible shapes: dome-like, elongated, and disc-like nectary. The nectaries are always accompanied by elongated or spheroidal papillae. Various combinations of floral characters (e.g., the numbers of stamens and styles, the stigma shape, the nectary shape, ACWs, cuticular striation and the trichome type and distribution) of $P$. sect. Cephalophilon are useful when attempting to recognize the infrasectional levels of $P$. sect. Cephalophilon recently proposed. Here, we describe the floral characteristics in detail and discuss the taxonomic significance of the floral characters.
\end{abstract}

Keywords: floral organ, nectary, SEM, tepal epidermal cells, tepal micromorphology, trichome

The micromorphology of the perianth has long been of interest to many researchers, and it is useful to understand in relation to environmental factors (e.g., light capturing or reflectance, and changes of the temperature and/or humidity) and pollinators (e.g., visible or olfactory attraction, or tactile contact) (Gale and Owens, 1983; Hong et al., 1998; Whitney et al., 2011; Ojeda et al., 2012; Costa et al., 2017). The micromorphological features of the perianth, such as anticlinal cell walls (ACWs), cuticular striation and trichome, have proven to be taxonomically useful within the angiosperm group (e.g., Allium, Leguminosae, and Asteraceae) (Barthlott, 1990; Paton, 1992; Moon and Hong, 2004; Ojeda et al., 2009; Choi et al., 2011; Çildir et al., 2012). In Polygonaceae, the perianth (tepal) micromorphology has been also consistently studied with special attention paid to the surface sculpturing of the tepal and nectary types (Ronse Decraene and Akeroyd, 1988; Ronse Decraene and Smets, 1991; Hong et al., 1998; Hong, 2001; Kim et al., 2001). In addition, the taxonomic significance of the stamen characteristics has been emphasized at the infrageneric or species level of Polygonaceae (Hong et al., 1998; Kim et al., 2001). Ronse Decraene and Akeroyd (1988) attempted to clarify the taxonomic delimitation within Polygonum s.l. based on the tepal micromorphology together with other floral features (e.g., the number of stamens and styles, and the nectary type). Although studies of floral characters in P. sect. Cephalophilon can also be found in the literatures (e.g., Ronse Decraene and Smets, 1991; Hong et al., 1998), these studies were performed on restricted taxa. Detailed studies of the floral characters of $P$. sect. Cephalophilon have not been conducted at the infrasectional level.

\footnotetext{
*Author for correspondence: sphong@khu.ac.kr
} 
The section Cephalophilon as a section of Persicaria is distributed mainly in the Asian region (Haraldson, 1978; Li et al., 2003; Freeman and Reveal, 2005). This section is distinguished from other sections of Persicaria based on capitate inflorescence, a stem without prickles and petiole which are usually winged (Meisner, 1832; Li et al., 2003; Freeman and Reveal, 2005). In early studies, the section Cephalophilon was recognized as one of the sections within Polygonum s.l., but various morphological studies and molecular phylogenies have suggested that the taxa of Cephalophilon belong to Persicaria (Haraldson, 1978; Hong et al., 1998; Ronse Decraene et al., 2000; Lamb Frye and Kron, 2003; Schuster et al., 2015). However, the sectional delimitation or species composition of Persicaria sect. Cephalophilon remain controversial. For example, some taxa which now belong to Koenigia (cf., Appendix 1) were included under Polygonum sect. Cephalophilon based on the inflorescence type and the number of tepals and styles ( $\mathrm{Li}$ et al., 2003; Zhu et al., 2007). Although many studies have supported that Koenigia taxa are separate from Polygonum s.l. (Hedberg, 1997; Hong et al., 1998; Ronse Decraene et al., 2000; Zhao et al., 2012; Schuster et al., 2015), this taxonomic confusion continues with the two genera. In addition, four new series (series Annui, series Criopolitana, series Palmatifolia, and series Perennes) of Polygonum sect. Cephalophilon have been suggested based on the habit (annual or perennial) and leaf characteristics (shape, and stomatal complex type and ACWs on the abaxial side), and this newly suggested system includes some taxa of Koenigia (Zhu et al., 2007). Thus, it is necessary to clarify the taxonomic delimitation of $P$. sect. Cephalophilon based on reliable characteristics.

As it is believed that the floral characteristics may provide additional evidence to clarify the taxonomic delimitation of $P$. sect. Cephalophilon, we investigated the detailed floral characteristics of $P$. sect. Cephalophilon. Thus, this study aims to present a detailed description of the floral organs and tepal micromorphology, including the epidermis and trichome, of $P$. sect. Cephalophilon using stereomicroscopy (SM) and scanning electron microscopy (SEM) and to evaluate the taxonomic implications of the studied floral characters in $P$. sect. Cephalophilon.

\section{Materials and Methods}

In total, 23 taxa (19 taxa in Persicaria sect. Cephalophilon and four taxa related to Koenigia) were investigated in the present study (see Appendix 1). Most materials were herbarium specimens sourced from the following herbaria: K, KHUS,
KUN, UPS, WU, and PE. Acronyms are in accordance with Thiers (2018) [continuously updated].

For the observations of the tepals, the flowers were initially examined using a SM (SteREO Discovery V8, Carl Zeiss Microscopy GmbH, Jena, Germany) in order to select fully mature flowers. The selected flowers were rehydrated for 24 $\mathrm{h}$ (Agepon wetting agent:distilled water $=1: 200$ ), and the rehydrated flowers were observed using SM. For the SEM observations, the rehydrated materials were dehydrated through an ethanol series $(50 \%, 70 \%, 90 \%, 95 \%$, and $100 \%$ ethanol) at room temperature for $1 \mathrm{~h}$ each. The completely dehydrated samples were immersed in liquid carbon dioxide for critical point drying (SPI-13200J-AB, SPI Supplies, West Chester, USA). The dried samples were fixed on aluminum stubs with double-adhesive carbon tape. The stubs were then coated with platinum using an ion-sputtering device (E-1045, Hitachi, Tokyo, Japan). The prepared floral organs were observed using a field-emission scanning electron microscope (FE-SEM, S4700 , Hitachi) at an accelerating voltage of $10 \mathrm{kV}$ with a working distance of $10-13 \mathrm{~mm}$. For micromorphological observations and floral organ size measurements, five samples per specimen of each taxon were measured using software (Macnification 2.0 version, Orbicule, Leuven, Belgium). In some taxa cases, the average values of the samples could not be determined; however, these taxa were included for a comparison of their flower morphologies with those of other taxa. The terminology of tepal epidermis micromorphology follows those in Barthlott (1990) and Hong et al. (1998).

\section{Results}

\section{Floral characteristics of Persicaria sect. Cephalophilon and taxa related to Koenigia}

The flowers of Persicaria sect. Cephalophilon usually consist of (four-)five-lobed tepal which are connate at the middle or base, and the tepal consists of two inner tepal lobes, one intermediate lobe, and two outer lobes. The tepal lobes of $P$. sect. Cephalophilon were elliptic in general, though they were also found to be narrowly obovate or obovate in shape. The tepal size of the section varied (length $\times$ width: 1.08-4.51 $\times$ 0.32-2.22 mm) (Table 1). Among the studied taxa, comparatively larger tepal lobes were observed in P. strindbergii $(3.70 \times 1.64$ $\mathrm{mm}$; investigated specimens, Henry 10499A) and P. chinensis var. ovalifolia $(3.63 \times 1.80 \mathrm{~mm})$, whereas rather smaller tepal lobes were observed in $P$. humilis $(1.29 \times 0.44 \mathrm{~mm})$ and $P$. glacialis var. glacialis $(1.25 \times 0.44 \mathrm{~mm})$. In the Koenigia taxa, the sizes of the tepal lobes were smaller than those in $P$. sect. Cephalophilon taxa $(0.80-1.55 \times 0.40-1.11 \mathrm{~mm})$ (Table 1). The 
Table 1. Overview of the floral morphological characteristics of Persicaria section Cephalophilon and taxa related to Koenigia

\begin{tabular}{|c|c|c|c|c|c|c|c|c|c|c|c|c|c|c|c|}
\hline \multirow{2}{*}{ Taxon/Characters } & \multicolumn{10}{|c|}{ Floral organs } & \multicolumn{3}{|c|}{ Tepal inside } & \multicolumn{2}{|c|}{ Tepal outside } \\
\hline & TL & TW & TR & TS & FL & FN & SL & SN & $\mathrm{OL}$ & OW & $\overline{\mathrm{ACW}}$ & $\mathrm{CS}$ & $\overline{\mathrm{TC}}$ & $\overline{\mathrm{ACW}}$ & CS TC \\
\hline \multicolumn{16}{|l|}{$\overline{\text { series Annui }}$} \\
\hline P. glacialis var. glacialis & $1.08(1.25) 1.47$ & $0.32(0.44) 0.62$ & 20.3 & ell & $.17(0.19) 0.20$ & 6 & $0.16(0.24) 0.35$ & 3 & 0.28 & 0.24 & cur & + & PT & str/cur & \\
\hline P. glacialis var. przewalskii & $2.94(3.17) 3.94$ & $0.97(1.00) 1.03$ & 69.9 & ell & $0.62(0.75) 0.88$ & 6 & $0.45(0.51) 0.56$ & 2 & $1.23(1.25) 1.27$ & $0.68(0.74) 0.88$ & cur & + & - & str/cur & $-/+\mathrm{P} T$ \\
\hline P. humilis & $1.23(1.29) 1.46$ & $0.38(0.44) 0.47$ & 61.2 & ell & $0.21(0.25) 0.28$ & 5 & $0.14(0.17) 0.21$ & 2 & $0.46(0.48) 0.50$ & $0.29(0.31) 0.33$ & cur & - & - & str/cur & - \\
\hline P. nepalensis 1 & $2.30(2.34) 2.37$ & $1.01(1.03) 1.06$ & 54.1 & ell & $0.57(0.79) 1.02$ & 6 & $0.35(0.41) 0.52$ & 2 & $0.54(0.94) 1.18$ & $0.43(0.65) 0.87$ & cur/und & + & - & str/cur & + \\
\hline P. nepalensis 2 & $2.56(2.63) 2.69$ & $0.57(0.75) 0.93$ & 59.5 & ell & $0.45(0.70) 0.93$ & 6 & $0.21(0.36) 0.46$ & 2 & $0.63(0.90) 1.17$ & $0.30(0.72) 1.13$ & cur/und & +/++ & - & str/cur & + \\
\hline $\begin{array}{l}\text { P. sinuata* } \\
\text { series Criopolitana }\end{array}$ & $1.60(1.97) 2.39$ & $0.80(0.91) 0.98$ & 49.0 & $\mathrm{ob}$ & $0.40(0.59) 0.77$ & 6 & $0.40(0.45) 0.51$ & 3 & $0.38(0.43) 0.48$ & $0.28(0.30) 0.31$ & cur/und & + & - & str/cur & + \\
\hline $\begin{array}{c}\text { P. criopolitana } \\
\text { series Palmatifolia }\end{array}$ & $3.16(3.21) 3.26$ & $1.19(1.35) 1.51$ & 35.0 & $\mathrm{ob}$ & $1.01(1.07) 1.12$ & 5 & $0.56(0.63) 0.73$ & 2 & $0.54(0.61) 0.70$ & $0.26(0.39) 0.50$ & und $/ \sin$ & ++ & - & str/cur & $++\mathrm{LT}$ \\
\hline $\begin{array}{c}\text { P. palmata } \\
\text { series Perennes }\end{array}$ & $2.39(2.53) 2.67$ & $0.73(0.86) 1.00$ & 50.0 & ell, nob & $0.46(0.74) 0.90$ & 8 & $0.65(0.82) 1.16$ & 3 & $0.44(0.48) 0.52$ & $0.35(0.39) 0.43$ & cur/und & $+/++$ & - & str/cur & $-/+\mathrm{PT}$ \\
\hline P. capitata & $2.35(2.64) 3.01$ & $0.85(1.04) 1.23$ & 40.9 & ell & $0.91(1.36) 1.78$ & 8 & $0.34(0.40) 0.47$ & 3 & $0.54(0.57) 0.61$ & $0.39(0.43) 0.46$ & cur/und & ++ & - & str/cur & $+\mathrm{PT}$ \\
\hline P. chinensis var. chinensis & $3.28(3.34) 3.40$ & $1.04(1.18) 1.31$ & 45.5 & $\mathrm{ob}$ & $0.43(1.10) 1.77$ & 8 & $0.42(0.92) 1.15$ & 3 & $0.72(0.83) 1.00$ & $0.39(0.62) 1.01$ & cur/und & ++ & - & str/cur & - \\
\hline P. chinensis var. ovalifolia & $3.12(3.63) 3.92$ & $1.36(1.80) 2.03$ & 34.8 & $o b$ & $1.78(1.94) 2.19$ & 8 & $1.07(1.14) 1.24$ & 3 & $0.70(0.74) 0.77$ & $0.46(0.50) 0.55$ & cur/und & $+/++$ & - & cur/und & $++\mathrm{P}$ \\
\hline P. chinensis var. paradoxa & $2.42(2.81) 3.62$ & $0.96(1.28) 1.61$ & 46.6 & $\mathrm{ob}$ & $0.72(1.25) 2.13$ & 8 & $0.43(0.57) 0.75$ & 3 & $0.45(0.73) 0.93$ & $0.37(0.47) 0.57$ & und & ++ & - & str/cur & \\
\hline P. chinensis var. hispida & $3.11(3.18) 3.29$ & $1.14(1.41) 1.68$ & 56.1 & $o b$ & $1.04(1.36) 1.74$ & 8 & $0.47(0.55) 0.60$ & 3 & 0.86 & 0.67 & und & ++ & - & str/cur & + \\
\hline P. microcephala var. microcephala & $2.52(2.78) 3.19$ & $0.75(1.07) 1.30$ & 52.7 & ell, ob & $0.73(1.07) 1.37$ & 8 & $0.36(0.40) 0.43$ & 3 & $0.48(0.68) 1.01$ & $0.37(0.50) 0.74$ & cur/und & ++ & - & cur/und & ++ \\
\hline P. microcephala var. sphaerocephala & $2.17(2.29) 2.48$ & $1.10(1.22) 1.32$ & 35.8 & ell, ob & $0.58(0.88) 1.14$ & 8 & $0.39(0.41) 0.42$ & 3 & $0.51(0.53) 0.55$ & $0.37(0.40) 0.42$ & cur & ++ & - & 1 & \\
\hline P. microcephala var. wallichii & $2.09(2.35) 2.60$ & $0.80(1.00) 1.11$ & 43.0 & ell & $0.40(0.56) 0.77$ & 8 & $0.39(0.47) 0.55$ & 3 & $0.43(0.45) 0.47$ & $0.24(0.29) 0.33$ & cur/und & ++ & - & cur/und & ++ PT \\
\hline P. runcinata var. runcinata & $2.21(2.62) 4.37$ & $1.17(1.43) 1.93$ & 20.2 & ell, nob & $0.74(1.14) 2.19$ & 8 & $0.40(0.71) 0.95$ & $3(4)$ & $0.47(0.59) 0.69$ & $0.34(0.42) 0.45$ & cur/und & ++ & - & cur/und & \\
\hline P. runcinata var. sinensis & $2.08(2.90) 3.73$ & $1.20(1.48) 1.83$ & 44.5 & ell, nob & $0.39(1.14) 2.25$ & 8 & $0.61(0.63) 0.65$ & 3 & 0.71 & 0.61 & cur & ++ & - & str/cur & ++ PT \\
\hline P. strindbergii 1 & $3.34(3.70) 4.51$ & $1.58(1.64) 1.69$ & 53.6 & ell, ob & $0.85(1.07) 1.27$ & $6 / 8$ & $0.85(1.17) 1.66$ & 3 & $0.56(0.71) 0.83$ & $0.36(0.46) 0.52$ & cur/und & + & - & str/cur & \\
\hline P. strindbergii 2 & $2.46(3.08) 3.85$ & $1.25(1.50) 2.22$ & 41.9 & $\mathrm{ob}$ & $1.51(1.91) 2.45$ & 8 & $0.53(0.54) 0.55$ & 3 & $0.49(0.75) 1.01$ & $0.33(0.43) 0.54$ & cur/und & + & - & str/cur & + \\
\hline P. umbrosa & $1.38(1.87) 2.29$ & $0.91(1.05) 1.16$ & 40.6 & $\mathrm{ob}$ & $0.53(0.78) 0.95$ & $6 / 8$ & $0.21(0.34) 0.72$ & 3 & $0.18(0.42) 0.55$ & $0.15(0.29) 0.37$ & cur/und & ++ & - & str/cur & ++ PT \\
\hline \multicolumn{16}{|l|}{ Koenigia spp. } \\
\hline K. delicatula & $0.80(0.99) 1.22$ & $0.40(0.50) 0.59$ & 39.4 & $\mathrm{ob}$ & $0.17(0.21) 0.23$ & 8 & $0.09(0.11) 0.13$ & 3 & $0.27(0.29) 0.30$ & $0.21(0.21) 0.22$ & und $/ \sin$ & ++ & - & $\sin$ & ++ \\
\hline K. islandica & $0.92(1.04) 1.13$ & $0.45(0.55) 0.61$ & 41.8 & ell, ob & $0.19(0.21) 0.21$ & 3 & $0.08(0.09) 0.09$ & 2 & 0.40 & 0.28 & und $/ \sin$ & ++ & PT & $\sin$ & ++ PT \\
\hline K. nepalensis 1 & $1.41(1.46) 1.51$ & $0.66(0.73) 0.81$ & 37.0 & $\mathrm{ob}$ & $0.20(0.22) 0.24$ & 8 & $0.07(0.11) 0.13$ & 3 & $0.63(0.67) 0.72$ & $0.49(0.52) 0.54$ & und $/ \sin$ & ++ & PT & und & ++ PT \\
\hline K. nepalensis 2 & $1.39(1.47) 1.53$ & $1.04(1.07) 1.10$ & 29.3 & $\mathrm{ob}$ & $0.35(0.37) 0.43$ & 8 & $0.10(0.10) 0.11$ & 3 & 0.23 & 0.17 & und $/ \sin$ & ++ & PT & $\sin$ & ++ \\
\hline K. pilosa & $0.91(1.25) 1.55$ & $0.51(0.74) 0.90$ & 32.0 & $o b$ & $0.10(0.27) 0.45$ & 8 & $0.09(0.10) 0.11$ & 3 & 0.37 & 0.29 & und $/ \sin$ & ++ & PT & $\sin$ & \\
\hline
\end{tabular}

\section{All measurements are in millimeters $(\mathrm{mm})$}

TL, tepal length; TW, tepal lobe width; TR, percentage (\%) of tepal connate degrees; TS, tepal lobes shape; FL, filament length; FN, number of filaments; SL, style length; SN, number of divided styles; OL, ovary length; OW, ovary width; ACW, anticlinal cell walls; CS, cuticular striation; TC, trichome type; ell, elliptic; ob, obovate; nob, narrowly obovate; cur, curved; und, undulate; sin, sinuate; str, straight; -, absent or less developed; +, developed; ++, well-developed; PT, peltate glandular trichome; LT, long-stalked pilate glandular trichome; /, unclear; *, the taxon was not included in the new infrasectional classification suggested by Zhu et al. (2007). 


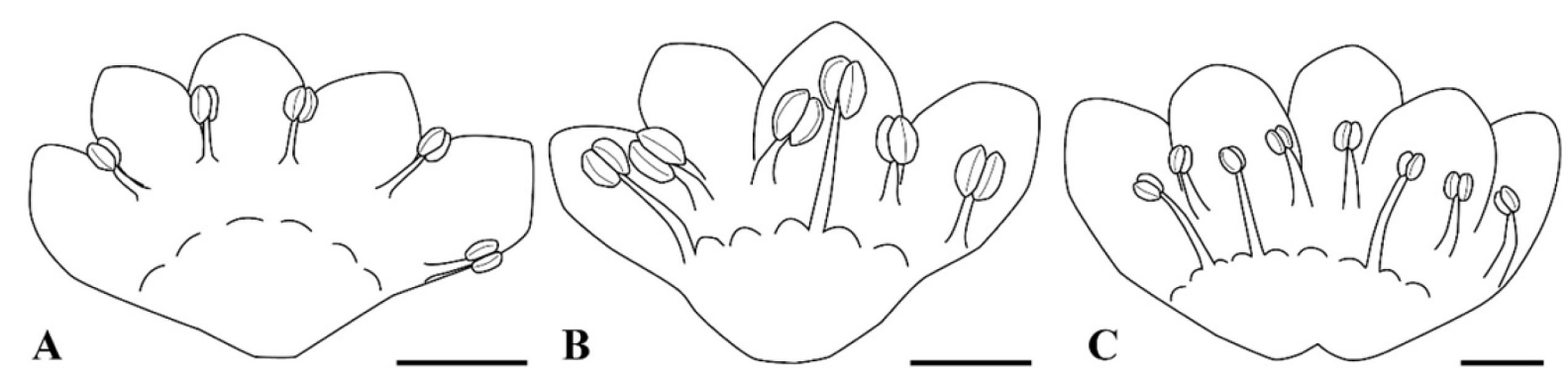

Fig. 1. Drawings of stamen arrangements within Persicaria sect. Cephalophilon. A. P. humilis, five stamens are distributed in a row on opposite tepal lobes. B. P. nepalensis, six stamens are distributed along two whorls consisting of two inner stamens which adnate with a nectary and four outer stamens. C. P. chinensis var. chinensis, eight stamens are distributed along two whorls consisting of three inner stamens and five outer stamens. Scale bars $=500 \mu \mathrm{m}$.

basal parts of the tepal lobes were connate, and the tepal connate degrees also varied, ranging from $20.2 \%$ to $69.9 \%$ of the overall tepal length.

$P$. sect. Cephalophilon had five, six, or eight stamens which are adnate with the tepal epidermis and nectary (Fig. 1, Table 1). The stamens were usually distributed along two whorls in cases with six or eight stamens (Fig. 1B, C). The outer whorl consisted of four to five stamens which were adnate with opposite tepal lobes, and the inner whorl consisted of two to three stamens which were adnate with nectaries (Figs. 1B, C, 2C). In addition, five stamens were distributed in a row on opposite tepal lobes (Fig. 1A). The shape of the filament was conical and narrow at the apex. Koenigia taxa usually had eight stamens while $K$. islandica had three stamens (Table 1). The Koenigia taxa except $K$. islandica also had stamens adnate with tepals and nectaries along with two whorls. The stamens of $K$. islandica were also adnate with nectaries. Occasionally, the outer stamens of $K$. delicatula and $K$. nepalensis were found to have staminodes. The range of the filament length was 0.10 $2.45 \mathrm{~mm}$; it is $0.17-2.45 \mathrm{~mm}$ in $P$. sect. Cephalophilon, while it is $0.10-0.45 \mathrm{~mm}$ in the Koenigia taxa (Table 1). In $P$. sect. Cephalophilon, the shortest filament was observed in $P$. glacialis var. glacialis, and the longest filament was observed in $P$. chinensis var ovalifolia (Table 1).

P. sect. Cephalophilon had one pistil with two or three divided styles (Fig. 2H-M, Table 1). The styles of this section are connate at the basal part; however, the connate length of the style (or divided length) was different for each taxon. The styles of Koenigia taxa were also divided into two or three divided styles from the ovary; however, a connated style at the basal part was not found (Fig. 2N, O). In most taxa, the stigma was capitate shaped (Fig. $2 \mathrm{H}-\mathrm{K}, \mathrm{N}, \mathrm{O}$ ), while only P. palmata had an elongated stigma (Fig. 2L, M). The range of the ovary size was $0.23-1.27 \times 0.15-1.13 \mathrm{~mm}$ (Table 1). Koenigia taxa had a smaller ovary size $(0.23-0.72 \times 0.17-0.54 \mathrm{~mm})$ in comparison with those of $P$. sect. Cephalophilon (0.23-1.27 $\times$ $0.15-1.13 \mathrm{~mm})$.

\section{Micromorphological features of the tepal epidermis}

The tepal epidermis was composed of elongated rectangular cells (i.e., tabular flat cells) with straight to sinuate ACWs and cuticular striation (Fig. 3A-I). The upper part of the tepal inside of $P$. sect. Cephalophilon had curved to undulated ACWs with well-developed cuticular striation in general (Fig. 3A, Table 1). The basal part of the tepal consisted of curved or straight ACWs which were indistinct in comparison with the upper part. Moreover, cuticular striation was not found on the basal part of the tepal (Fig. 3B). The upper part of the tepal outside epidermis of $P$. sect. Cephalophilon usually had straight to curved ACWs, although some taxa had curved to undulated ACWs (Fig. 3G, H, Table 1). However, P. criopolitana had undulated to sinuated ACWs on the upper part of the tepal inside as opposed to other taxa within $P$. sect. Cephalophilon (Fig. 3E). Koenigia taxa had sinuated ACWs with welldeveloped cuticular striation on upper part of tepal inside, and Koenigia taxa had also undulated or sinuated ACWs on the upper part of the tepal outside (Fig. 3F, I). Stomata on the tepal epidermis were rarely observed in the studied taxa (Fig. 3A, C).

Two types of glandular trichomes were observed on tepal epidermis: peltate glandular trichome (PT) and long-stalked pilate glandular trichome (LT) (Fig. 3G, J-L, Table 1), while the non-glandular trichomes were not found in this study. The PTs were usually distributed on the outside of the tepal in $P$. sect. Cephalophilon, while the PTs of Koenigia taxa were distributed on both sides (Table 1), except in two taxa (P. glacialis var. glacialis and $K$. delicatula). The LTs were only observed on the basal part of the outer tepal in P. criopolitana (Fig. 3J).

The floral nectary with papillae was located at the basal part of the tepal inside (Fig. 2A-G). Most taxa had a dome-shaped 

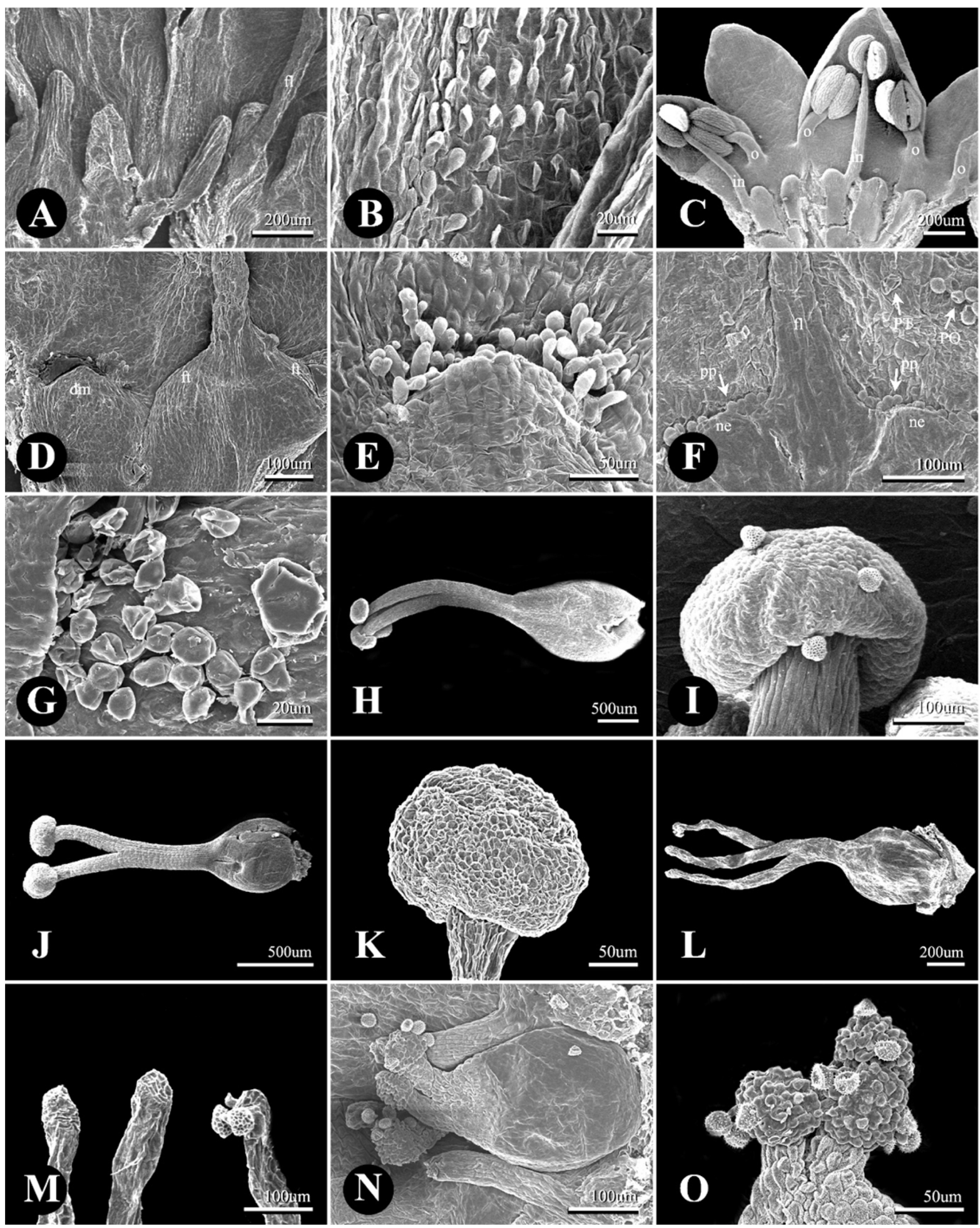

Fig. 2. Scanning electron micrographs of the pistil, stigma, and nectary with papillae in Persicaria sect. Cephalophilon and taxa related to Koenigia. A-G. Nectary with papillae. A, B. Elongated shaped nectaries of $P$. palmata, fil, filament. C. Inside of the tepal with dome-like nectaries of $P$. nepalensis. o, stamens along the outer whorl; in, stamens along the inner whorl. D. P. umbrosa with both a dome-like nectary (dm) and flat-shaped nectaries (ft). E. P. chinensis var. ovalifolia, dome-like nectary with papillae. F. K. pilosa, disc-like nectaries with papillae. fl, filament; ne, nectary; pp, papillae; PT, peltate glandular trichome; PO, pollen grains. G. Spheroidal-shaped papillae of $K$. nepalensis. H-O. Pistil. H, I. P. chinensis var. chinensis, three-divided styles with capitate stigma. J, K. P. criopolitana, two divided styles with capitate stigma. L, M. P. palmata, three divided styles with elongated stigma. N, O. K. delicatula, three divided styles with capitate stigma. 

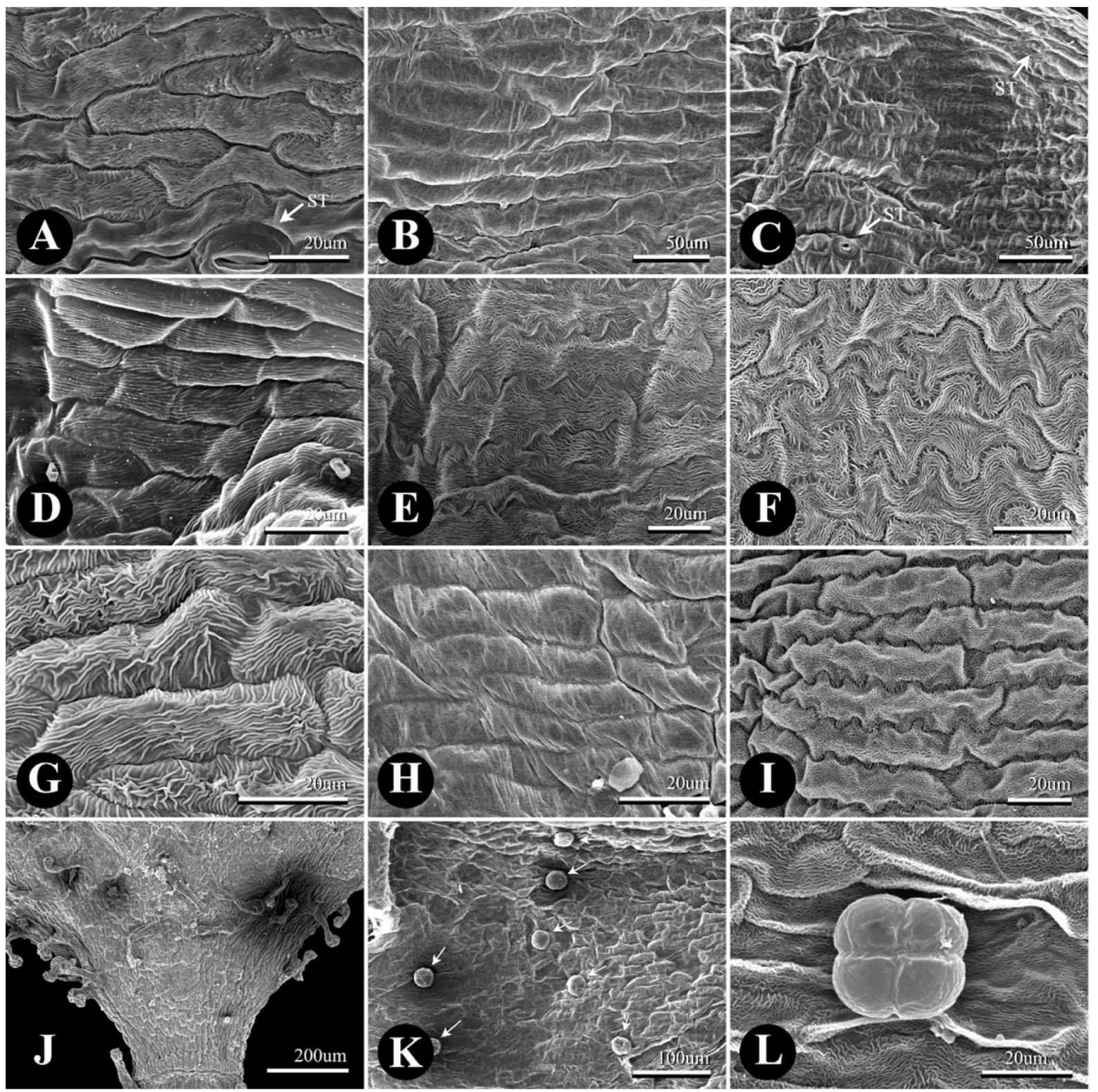

Fig. 3. Scanning electron micrographs of the tepal epidermis in Persicaria sect. Cephalophilon and taxa related to Koenigia. A-F. Epidermis of the tepal inside. G-I. Epidermis of the tepal outside. J-L. Observed glandular trichomes. A, B. P. chinensis var. ovalifolia (in). A. Undulate and curved anticlinal cell walls (ACW) with well-developed cuticular striation on the upper part. B. Straight or curved ACW with on the basal part. C. P. glacialis var. przewalskii, straight or curved ACW with weakly cuticular striation on the upper part (in). D. P. nepalensis, straight or curved ACW with weakly cuticular striation on the upper part (in). E. P. criopolitana, sinuated and undulated ACW with well-developed cuticular striation on the upper part (in). F. K. delicatula, sinuated and undulated ACW with well-developed cuticular striation on the upper part (in). G. . chinensis var. ovalifolia on the upper part (out). H. P. humilis on the upper part (out). I. K. nepalensis on the upper part (out). J. P. criopolitana with LT on the basal part (out). K. P. strindbergii, PT with four-celled head (white arrows) (out). L. K. nepalensis with PT (in). in, inside of tepal; out, outside of tepal; ST, stomata; LT, long-stalked pilate glandular trichome; PT, peltate glandular trichome.

nectary which had a wider width than the length (Fig. 2C-E). However, some taxa had other types of nectaries; for example, $P$. palmata had a cylindrical nectary which is longer than its width (Fig. 2A), and P. runcinata var. runcinata had both dome-shaped and cylindrical nectaries. With regard to $P$. umbrosa, the independent nectary had a dome shape, but the nectary which adnate to the stamen resembled the inflated base of a filament (Fig. 2D). The nectaries of Koenigia taxa were fused into disc-like structures (Fig. 2F). The papillae shape also distinguished $P$. sect. Cephalophilon from Koenigia (Table 
1). The papillae of $P$. sect. Cephalophilon had elongated shapes, while those of Koenigia had spheroidal shapes (Fig. 2E, F).

\section{Discussion}

General flower features, such as the number of tepal lobes, stamens and styles, are similar to those of other taxa in Persicarieae (Ronse Decraene and Akeroyd, 1988; Hedberg, 1997; Kim et al., 2001; Li et al., 2003; Freeman and Reveal, 2005). The androecium could be considered as basically polymerous (Ronse Decraene and Smets, 1987). Eight stamens represent a primitive number in Polygonum, and variation of the number of stamens may have occurred in different locations (Ronse Decraene and Akeroyd, 1988). In this study, the reduction of the stamen number may be related to the stamens in the inner whorl in a comparison between taxa with eight stamens and with five stamens. However, when comparing eight stamens with six stamens, the reduction is considered to occur in both the inner and outer whorls. In addition, it is difficult to explain the change from six stamens to five stamens. Therefore, additional studies are needed to confirm whether there is a tendency in this regard.

A dimerous gynoecium is always associated with the loss of the inner stamens (Ronse Decraene and Akeroyd, 1988). There is the correlation with regard to reductions between the number of stamens and styles in most of the taxa in the present study; however, this tendency is not relevant in Koenigia taxa (Table 1). The taxa with three styles had eight stamens, while the taxa which had two styles had five or six stamens (Table 1), although some taxa had three styles with six stamens (e.g., P. glacialis var. glacialis, P. sinuata, P. strindbergii 1 , and $P$. umbrosa) (Table 1). These stamen numbers are partially supported by a recently suggested infrasectional system within P. sect. Cephalophilon. For example, most taxa of the series Annui and series Criopolitana have five or six stamens with two divided styles except for $P$. glacialis var. glacialis and $P$. sinuata. In addition, the series Perennes and Palmatifolia are supported by eight stamens and three divided styles.

The cuticular striations are well developed on the upper part of the tepal inside as compared to the epidermis of the basal part, which has a smooth surface. These features are consistent with the findings of previous studies (Ronse Decraene and Akeroyd, 1988; Hong et al., 1998). A remarkable finding is that weak striations could be a putative character of the series Annui (Zhu et al., 2007), in addition, this series is characterized by five or six stamens usually with two styles. The cuticular striation may be correlated with the habitat conditions (Hong et al., 1998); however, the studied taxa of $P$. sect.
Cephalophilon are known to have similar habitat features and altitudes in general, such as mountain slopes, grassy slopes, shaded places, and thickets in valleys (Li et al., 2003; Freeman and Reveal, 2005; Kong and Hong, unpublished data).

The diversity of the trichome types and their distribution patterns were also emphasized as having taxonomic significance in previous studies (Ronse Decraene and Smets, 1991; Moon and Hong, 2004; Çildir et al., 2012). PTs are consistently observed in all of the studied taxa except for $P$. criopolitana, and the distribution of PTs on the tepal is also a useful characteristic. The Koenigia taxa and P. glacialis var. glacialis have PTs on both sides of the tepal, while most of P. sect. Cephalophilon has PTs only on the outer side of the tepal. LTs are observed in only P. criopolitana, and this type of trichome is also found on the abaxial side of the leaf epidermis (Kong and Hong, pers. observ.). The trichomes type is a useful characteristic to identify $P$. criopolitana together with the number of stamens and styles, and the sinuated/undulated type of ACWs on the upper epidermis of the tepal inside.

In all of the studied taxa, nectary structures with papillae were found, and this characteristic is a common feature in the Polygoneae and Persicarieae (Ronse Decraene and Smets, 1991). The nectary shape distinguished P. palmata of the series Palmatifolia within the section together with the stigma shape, and a disc-like nectary with spheroidal papillae is also useful to identify Koenigia taxa from the section. The nectaries may play an important role to attract pollinators, as the tepal epidermis of the studied taxa is composed of tabular cells which are known to reflect or absorb less light during the pollination process to attract insects as compared to papillae conical cells (Kay et al., 1981; Christensen and Hansen, 1998); In this case, moreover, the papillae have an important function that may help to retain nectar, to prevent pollen from dropping into the nectar, or to keep the nectar moist (Ihlenfeldt, 1960; Rohweder, 1970; Zandonella, 1977; Ronse Decraene and Smets, 1991). The length or distribution area of the papillae is slightly different in each individual; however, detailed studies are necessary to determine whether this difference affects the ability to attract pollinators.

In conclusion, certain aspects of floral morphologies, such as the numbers of stamens and styles, the stigma shape, ACWs, cuticular striation, the trichome type and the nectary shape, are useful to recognize certain taxa of $P$. sect. Cephalophilon, and these characteristics are congruence with the delimitation of the series which were suggested by Zhu et al. (2007). Furthermore, our results, such as those pertaining to the floral organs size, style type, ACWs, cuticular striation, trichome distribution, and shape of the nectaries and papillae, also 
support the independence of the genus Koenigia (Hedberg, 1997; Hong et al., 1998; Ronse Decraene et al., 2000; Zhao et al., 2012; Schuster et al., 2015). However, sectional delimitation of $P$. sect. Cephalophilon in the genus remains unclear based on the floral morphological characters compared with earlier studies in which these characteristics were also found in P. sect. Echinocaulon and P. sect. Persicaria (Ronse Decraene and Akeroyd, 1988; Kim et al., 2001). Further study is needed to determine whether the floral characters are also useful at the infrasectional level for other sections of Persicaria, and sampling is necessary to clarify the systematic tendencies based on the floral morphologies in the genus together with molecular phylogeny studies with sufficient taxa.

\section{Acknowledgements}

We thank our colleagues at Kyung Hee University for helping us in various ways during the preparation of the manuscript. We give our sincere thanks to the editor and the anonymous reviewers for their insightful comments and suggestions to improve the manuscript. This work was supported by grants from the Basic Science Research Program through the National Research Foundation of Korea (NRF) funded by the Ministry of Education, Sciences and Technology [Grant numbers NRF-2015R1D1A1A01058462] to S.-P. Hong.

\section{Conflicts of Interest}

Authors declare that there are no conflicts of interest.

\section{Literature Cited}

Barthlott, W. 1990. Scanning electron microscopy of the epidermal surface in plants. In Scanning Electron Microscopy in Taxonomy and Function Morphology. Claugher, D. (ed.), Clarendon Press, Oxford. Pp. 69-94.

Choi, H. J., A. R. Davis and J. H. Cota-Sánchez. 2011. Comparative floral structure of four New World Allium (Amaryllidaceae) species. Systematic Botany 36: 870-882.

Christensen, K. I. and H. V. Hansen. 1998. SEM studies of epidermal patterns of petals in the angiosperms. Opera Botanica 135: 5-91.

Çildir, H., A. Kahraman and M. Dogan. 2012. Petal and sepal epidermal micromorphology of six Lathyrus taxa (Fabaceae) and their systematic value. Notulae Botanicae Horti Agrobotanici Cluj-Napoca 40: 35-41.

Costa, V. B. S., R. M. M. Pimentel, M. G. S. Chagas, G. D. Alves and C. C. Castro. 2017. Petal micromorphology and its rela- tionship to pollination. Plant Biology 19: 115-122.

Freeman, C. C. and J. L. Reveal. 2005. Polygonaceae. In Flora of North America. Vol. 5. Flora of North America Editorial Committee (ed.), Oxford University Press, New York. Pp. 479601.

Gale, R. M. O. and S. J. Owens. 1983. Cell distribution and surface morphology in petals, androecia and styles of Commelinaceae. Botanical Journal of the Linnean Society 87: 247-262.

Haraldson, K. 1978. Anatomy and taxonomy in Polygonaceae subfam. Polygonoideae Meissn. emend. Jaretzky. Symbolae Botanisk Upsalienses 22: 1-95.

Hedberg, O. 1997. The genus Koenigia L. emend. Hedberg (Polygonaceae). Botanical Journal of the Linnean Society 124: 295-330.

Hong, S.-P. 2001. Tepal surface micromorphology in the genus Fagopyrum Mill. (Polygonaceae) and its systematic implication. Proceedings of the 8th international symposium of buckwheat. Pp. 264-270

Hong, S.-P., L.-P. Ronse Decraene and E. Smets. 1998. Systematic significance of tepal surface morphology in tribes Persicarieae and Polygoneae (Polygonaceae). Botanical Journal of the Linnean Society 127: 91-116.

Ihlenfeldt, H. D. 1960. Entwicklungsgeschichtliche, morphologische und systematische Untersuchungen an Mesembryanthemum. Feddes Repertorium 63: 1-104.

Kay, Q. O. N., H. S. Daoud and C. H. Stirton. 1981. Pigment distribution, light reflection and cell structure in petals. Botanical Journal of the Linnean Society 83: 57-83.

Kim, M.-H., M. Kwak, J. Song, S. J. Lee, M.-J. Yoo and C.-W. Park. 2001. Morphology of hairs, flowers, and achenes of Polygonum section Echinocaulon Meisn. (Polygonaceae). Korean Journal of Plant Taxonomy 31: 143-160.

Lamb Frye, A. S. and K. A. Kron. 2003. rbcL phylogeny and character evolution in Polygonaceae. Systematic Botany 28: 326 332.

Li, A.-J., B. Bao, A. E. Grabovskava-Borodina, S.-P. Hong, J. McNeill, S. L. Mosyakin, H. Ohba and C.-W. Park. 2003. Polygonaceae. In Flora of China. Vol. 5. Wu, Z. Y., P. H. Raven and D. Y. Hong (eds.), Science Press, Beijing and Missouri Botanical Garden Press, St. Louis, MO. Pp. 277-350.

Meisner, C. F. 1832. Synopsis Polygonearum. In Plantae Asiaticae Rariores. Vol. 3. Wallich, N. (ed.), Treuttel and Würtz, London. Pp. 53-65.

Moon, H.-K. and S.-P. Hong. 2004. The taxonomic consideration of petal and sepal micromorphology in Lycopus L. (MentheaeLamiaceae). Korean Journal of Plant Taxonomy 34: 273-285.

Ojeda, I., S.-G. Arnoldo, C.-C. Juli, J.-M. Ruth, M. Águedo and C. B. C. Quentin. 2012. Comparative micromorphology of petals 
in Macaronesian Lotus (Leguminosae) reveals a loss of papillose conical cells during the evolution of bird pollination. International Journal of Plant Sciences 173: 365-374.

Ojeda, I., J. Francisco-Ortega and Q. C. B. Cronk. 2009. Evolution of petal epidermal micromorphology in Leguminosae and its use as a marker of petal identity. Annals of Botany 104: 1099-1110.

Paton, A. 1992. The adaptive significance of calyx and nutlet morphology in Scutellaria. In Advanced in Labiate Science. Harley, R. M. and T. Reynolds (eds.), Royal Botanic Gardens, Kew. Pp. 203-210.

Rohweder, O. 1970. Centrosperrnen-studien 4. Morphologie und Anatomie der Blüten, Früchte und Samen bei Alsinoideen und Paronychioideen s. lat. (Caryophyllaceae). Bot Jahrbucher 90: 201-271.

Ronse Decraene, L.-P. and J. R. Akeroyd. 1988. Generic limits in Polygonum and related genera (Polygonaceae) on the basis of floral characters. Botanical Journal of the Linnean Society 98 : 321-371.

Ronse Decraene, L.-P., S.-P. Hong and E. Smets. 2000. Systematic significance of fruit morphology and anatomy in tribes Persicarieae and Polygoneae (Polygonaceae). Botanical Journal of the Linnean Society 134: 301-337.

Ronse Decraene, L.-P. and E. Smets. 1987. The distribution and the systematic relevance of the androecial characters oligomery and polymery in the Magnoliophytina. Nordic Journal of Botany 7: 239-253.
Ronse Decraene, L.-P. and E. Smets. 1991. The floral nectaries of Polygonum s.l. and related genera (Persicarieae and Polygoneae): position, morphological nature and semophylesis. Flora 185: 165-185.

Schuster, T. M., J. L. Reveal, M. J. Bayly and K. A. Kron. 2015. An updated molecular phylogeny of Polygonoideae (Polygonaceae): relationships of Oxygonum, Pteroxygonum, and Rumex, and a new circumscription of Koenigia. Taxon 64: $1188-1208$.

Thiers, B. 2018. [continuously updated] Index Herbariorum: A global directory of public herbaria and associated staff. Retrieved Jun. 1, 2018, available from http://sweetgum.nybg.org/science/ih/.

Whitney, H. M., K. M. V. Bennett, M. Dorling, L. Sandbach, D. Prince, L. Chittka and B. J. Glover. 2011. Why do so many petals have conical epidermal cells? Annals of Botany 108: 609-616.

Zandonella, P. 1977. Apports de l'etude comparée des nectaires floraux â la conception phylogénétique de l'ordre des centrospermales par. Plant Biology 90: 105-125.

Zhao, D.-P., K.-M. Wang and Y.-T. Hou. 2012. Phylogeny of Polygonum sect. Cephalophilon (Polygonaceae) inferred from the chloroplast $t r n L-F, r b c L$ and nuclear ribosomal ITS sequences. Bulletin of Botanical Research 32: 77-83.

Zhu, L.-T., F.-J. Lu, Y.-T. Hou and F.-Z. Li. 2007. Micro-morphology of leaf epidermis and its taxonomic significance of Polygonum section Cephalophilon in China. Journal of Wuhan Botanical Research 25: 136-142. 
Appendix 1. Specimens examined for a floral morphological study of Persicaria sect. Cephalophilon and four taxa related to Koenigia.

\begin{tabular}{ll}
\hline \hline Taxa & Voucher specimens
\end{tabular}

Persicaria capitata (Buch.-Ham. ex D. Don) H. Gross

India, Sambalpur, Oct 1950, Mooney 4088 (K)

P. chinensis (L.) H. Gross var. chinensis

China, Yunnan, Sep 1924, Forrest 25182 (K)

P. chinensis var. hispida (Hook.f.) Kantachot

China, Guizhou, Sep 1986, Dang and Dang 569 (PE)

P. chinensis var. ovalifolia (Meisn.) H. Hara

Nepal, Nov 1973, Schilling S1101 (K)

P. chinensis var. paradoxa (H. Lév.) B. Li

China, Yunnan, -, Henry 9279A (K)

P. criopolitana (Hance) Migo

P. glacialis (Meisn.) H. Hara var. glacialis

P. glacialis var. przewalskii (A.K. Skvortsov \& Borodina) M.-J. Kong \& S.-P. Hong (nom. ined.)

P. humilis (Meisn.) H. Hara

P. microcephala (D. Don) H. Gross var. microcephala

P. microcephala var. sphaerocephala (Wall. ex Meisn.) H. Hara

P. microcephala var. wallichii (Meisn.) H. Hara

China, Hunan, Sep 2005, Xiao 4844 (K)

China, Yunnan, Jul 1915, Handel-Mazzetti 7087 (WU)

China, Shaanxi, Oct 1958, Guixing 397 (KUN)

China, Yunnan, Aug 2000, Hua et al. 9347 (KUN)

India, Asam, Aug 1908, Crail s.n. (K)

China, Sichuan, Jun 2011, Bashan Exp. 4906 (PE)

P. nepalensis (Meisn.) H. Gross 1

P. nepalensis (Meisn.) H. Gross 2

P. palmata (Dunn) Yonek. \& H. Ohash

P. runcinata (Buch.-Ham. ex D. Don) H. Gross var. runcinata

P. runcinata var. sinensis (Hemsley) B. Li

China, Tibet, Jun 1975, The Qinghai-Tibet team 6676 (PE)

Korea, Gyeonggi-do, Sep 2011, Kong 7 (KHUS)

Korea, Gyeonggi-do, Sep 2012, Kong s.n. (KHUS)

China, Hunan, Oct 1974, - 1223 (PE)

China, Yunnan, Jun 1994, ACE 447 (K)

P. sinuata (Royle ex Bab.) K. R. Rajbhandari \& R. Joshi

China Yunnan, Mar 1933, McLaren Mc/L/B103 (K)

Indonesia, Kumaon, -, Strachey and Winterbottom $40(\mathrm{~K})$

China, Yunnan, -, Henry 10499A (K)

P. strindbergii (J. Schust.) Galasso 1

China, Yunnan, Mar 2006, Shui and Chen 70257 (PE)

P. strindbergii (J. Schust.) Galasso 2

P. umbrosa (Sam.) Galasso

China, Yunnan, Jul 1916, Handel-Mazzetti 9350 (WU)

Koenigia delicatula (Meisn.) H. Hara

China, Yunnan, Jul 2010, Zhang et al. 10 CS2114 (K)

K. islandica L.

Greenland, Sukkertoppen, -, Horsen 601 (UPS)

K. nepalensis D. Don 1

China, Tibet, 1897, Hobson s.n. (K)

K. nepalensis D. Don 2

China, Tibet, Au. 1975, Qinghai-Xizang Additional Exp. 751601 (PE)

K. pilosa Maxim.

China, Tibet, May 1893, Soulie 706 (K)

Herbarium acronyms are in accordance with Thiers (2018) [continuously updated]; -, without detailed collection information. 